\title{
PEMANFAATAN APLIKASI GOOGLE MEET SEBAGAI MEDIA PELAKSANAAN LAYANAN BIMBINGAN KLASIKAL SISWA SMAN 12 KOTA JAMBI
}

\author{
Desi Gusdarti $^{1}$, Hary Soedarto Harjono ${ }^{2}$, Eddy Haryanto ${ }^{3}$ \\ Mahasiswa Universitas Jambi, Dosen Universitas Jambi², \\ Dosen Universitas Jambi ${ }^{3}$ \\ Jalan Raden Mattaher No. 16 Jambi \\ Sur-el: desihabibie29@gmail.com ${ }^{1}$, hary.soedarto@unja.ac.id ${ }^{2}$, \\ eddy.haryanto@unja.ac.id ${ }^{3}$
}

Article info

Article history:

Received:18-06-2021

Revised :25-07-2021

Accepted:20-08-2021

Keywords:

Utilization, Google

Meet Media,

Classical Guidance

Services

Kata Kunci:

Pemanfaatan, Media

Google Meet,

Layanan Bimbingan

Klasikal

\section{A B S T R A C T}

The purpose of this study is to find out how to use the Google Meet application in the implementation of classical guidance services in students of class XII SMAN 12 Jambi City. This research method is a qualitative research method that uses purposive sampling techniques in data collection using unstructured interviews and triangulation, after which it is analyzed using qualitative descriptive to get an idea of the facts. The results of the study conducted by researchers through interviews with 5 informants about the use of google meet application as a medium of implementation of classical guidance services for students of class XII SMAN 12 Jambi City showed that the google meet application is the right choice to be used as a medium of implementation of classical guidance services because it meets the five principles of learning media, namely effectiveness, relevance, efficiency, usable and contextual.

Tujuan dalam penelitian ini adalah untuk mengetahui bagaimanakah pemanfaatan aplikasi Google Meet dalam pelaksanaan layanan bimbingan klasikal pada siswa kelas XII SMA N 12 Kota Jambi. Metode penelitian ini adalah metode penelitian kualitatif yang menggunakan teknik purposive sampling dalam pengumpulan data dengan menggunakan wawancara tak berstruktur serta triangulasi, setelah itu dianalisis menggunakan deskriptif kualitatif untuk mendapatkan gambaran mengenai fakta yang ada. Hasil penelitian yang dilakukan oleh peneliti melalui wawancara dengan 5 informan mengenai pemanfaatan aplikasi google meet sebagai media pelaksanaan layanan bimbingan klasikal bagi siswa kelas XII SMAN 12 Kota Jambi menunjukkan bahwa aplikasi google meet merupakan pilihan yang tepat untuk dimanfaatkan sebagai media pelaksanaan layanan bimbingan klasikal karena memenuhi lima prinsip media pembelajaran, yaitu efektivitas, relevansi, efisiensi, dapat digunakan dan kontekstual. 


\section{JURNAL ILMIAH \\ BINA EDUKASI \\ ISSN 1979-8598 E-ISSN: 2655-8378 \\ http://journal.binadarma.ac.id/index.php/jurnalbinaedukasi \\ Vol. 14, No. 2, Desember 2021, 107 - 120}

\section{PENDAHULUAN}

Kegiatan layanan bimbingan dan konseling yang diatur dalam permendikbud nomor 111 tahun 2014 merupakan layanan bantuan khusus yang lebih bersifat psiko-edukatif. Sebagaimana diketahui setiap peserta didik antara satu dengan yang lainnya berbeda dalam aspek kecerdasan, bakat, minat, kepribadian, kondisi fisik dan latar belakang keluarga serta pengalaman belajar yang menggambarkan adanya perbedaan masalah yang dihadapi peserta didik sehingga memerlukan layanan bimbingan dan konseling yang berbeda pula.

Dalam memperbaiki proses pelayanannya, konselor mulai menggunakan media-media yang mampu menunjang kebutuhan-kebutuhan para konseli terhadap kemandiriannya. Dunia online dapat dijadikan sarana dalam membantu guru bimbingan konseling untuk meng-update pengetahuannya guna membantu menjalankan tugas seperti mencari referensi, diskusi dan sebagainya. Seiring dengan itu penyelenggara konseling tidak hanya dilakukan secara face to face (FtF) dalam satu ruang tertutup, namun bisa dilakukan melalui format jarak jauh yang dibantu dengan teknologi yang selanjutnya dikenal dengan istilah e-counseling (Gibson dkk: 2008).

Berdasarkan diskusi peneliti dengan guru bimbingan konseling sesama anggota musyawarah guru mata pelajaran (MGBK) baik yang ada di Kota Jambi maupun Provinsi Jambi, sebagian besar dari mereka juga mengalami permasalahan yang sama dengan penulis dalam hal pelaksanaan layanan bimbingan klasikal.

Rasio jumlah guru bimbingan dan konseling dengan siswa binaan yang tidak sesuai standar dimana seharusnya satu orang guru bimbingan dan konseling memegang lima (5) kelas binaan sama hitungannya dengan 24 jam pelajaran. Namun kenyataan yang ada dilapangan SMAN 12 Kota Jambi kekurangan guru bimbingan dan konseling bahkan satu guru bimbingan dan konseling memegang 8 (delapan) kelas binaan. Hal ini terjadi tidak hanya di SMAN 12 Kota Jambi tetapi juga di kabupaten-kabupaten lain yang ada di Provinsi Jambi bahkan ada yang satu sekolah memiliki satu guru bimbingan konseling dengan jumlah siswa binaan mencapai 400 atau 500 peserta didik bahkan ada yang mencapai 1000 peserta didik. Tentu hal ini sangat tidak efektif, namun walau begitu guru harus mencari solusi pemecahan masalah agar layanan bimbingan klasikal dapat tetap terlaksana. Keadaan kurangnya sarana dan prasarana di SMAN 12 Kota Jambi yang belum memadai juga menjadi faktor penghambat kelancaran terlaksananya proses layanan bimbingan klasikal. 


\section{JURNAL ILMIAH \\ BINA EDUKASI \\ ISSN 1979-8598 E-ISSN: 2655-8378 \\ http://journal.binadarma.ac.id/index.php/jurnalbinaedukasi \\ Vol. 14, No. 2, Desember 2021, 107 - 120}

Pembelajaran berbasis teknologi informasi dan komunikasi (TIK) dalam dunia pendidikan keberadaannya tidak dapat dipisahkan dengan tuntutan pembelajaran abad-21. Dalam perspektif pendidikan global, TIK merupakan soko guru (penopang) efektifnya penyelenggaraan pendidikan. Bahkan TIK dalam perkembangannya mendorong semua elemen-elemen pendidikan modern, guru, siswa, orang tua, dan sekolah dituntut untuk adaftif dalam menyikapinya Sutrisno (2012).

Berdasarkan pernyataan tersebut tidak menutup kemungkinan bagi guru bimbingan dan konseling untuk ikut ambil bagian dalam pemanfaatkan kemajuan teknologi guna kelancaran proses pelaksanaan layanan bimbingan konseling agar tercapainya tujuan dari program bimbingan konseling yang sudah dirancang oleh guru bimbingan dan konseling yaitu kemandirian peserta didik. Berbagai macam teknologi dapat dimanfaatkan oleh guru bimbingan konseling guna kelancaran proses pelayanan. Tinggal keterampilan guru bimbingan dan konseling dalam memilih dan menggunakan teknologi yang sesuai dengan layanan yang diberikan kepada siswa/klien. Salah satu teknologi yang dapat digunakan untuk pelaksanaan layanan bimbingan konseling adalah aplikasi google meet.

Penggunaan aplikasi sebagai media juga dilakukan Bangun N, Br dan Saragih A,H, dengan judul penelitian "Pengembangan media web bimbingan konseling"(2015) hasil penelusuran dari angket yang disebar ditemukan bahwa 100\% siswa menyatakan membutuhkan media website bimbingan konseling agar dapat dijadikan sarana konsultasi yang lebih efektif tanpa harus bertatap muka dengan guru BK, sebanyak 43 siswa $(71,7 \%)$ dan menyatakan menggunakan atau memanfaatkan media website sebanyak 50 siswa $(83,3 \%)$ sebelum adanya sosialisasi mengenai media website, kemudian mayoritas siswa sebanyak 59 siswa $(98,3 \%)$ menyatakan tertarik dan mayoritas sebanyak 45 siswa $(75 \%)$ telah menggunakan media website sebagai pilihan alat layanan bimbingan konseling setelah dilakukan sosialisasi mengenai manfaat dan cara-cara penggunaan media website tersebut.

Penelitian pengembangan, Kurniawan. T. dan Winingsih (2019:2) berdasarkan data yang diperoleh dari SMPN Gresi kelas VII berjumlah 80 siswa memiliki smartphone android sebanyak $80 \%$ yaitu 64 siswa, smartphone iphone sebanyak $15 \%$ yaitu 12 siswa. Data tersebut sebagai pijakan membuat aplikasi berbasis android untuk mengenalkan bimbingan dan konseling.

Dari hasil penelitian Atmoko, Adi dkk (2018) didapat bahwa (1) sebagian kecil siswa (11\%) sudah mendengar mengenai layanan BK berbasis blended learning; dan (2) sebagian kecil $(7,8 \%)$ siswa yang pernah mengikuti kegiatan bimbingan dan konseling yang menggunakan blended learning; (3) sebagian besar siswa (79\%) menyebutkan bahwa proses bimbingan dan 


\section{JURNAL ILMIAH \\ BINA EDUKASI \\ ISSN 1979-8598 E-ISSN: 2655-8378 \\ http://journal.binadarma.ac.id/index.php/jurnalbinaedukasi \\ Vol. 14, No. 2, Desember 2021, 107 - 120}

konseling yang dilaksanakan di sekolahnya masih menggunakan kegiatan tatap muka di kelas, sebagian kecil siswa (6\%) menyebutkan proses bimbingan dan konseling yang dilaksanakan merupakan kegiatan online, dan sebagian kecil siswa (8\%) menyebutkan bahwa pelaksanaan bimbingan dan konseling di sekolah menggunakan campuran beberapa kegiatan tersebut, (4) sebagian siswa (38\%) siswa menyebutkan bahwa guru BK menyediakan buku, sebagian besar lainnya (72\%) siswa menyebutkan bahwa guru BK menyediakan bahan berupa power point, audio, video, informasi dari internet, aplikasi mobile, handout dan bahan berupa lisan, (5) sebagian besar $(88 \%)$ siswa menyebutkan bahwa kegiatan belajar yang dilakukan selama di sekolah hanya mendengarkan; di sisi lain sebagian besar (60\%) siswa pernah melakukan pembelajaran jarak jauh dan $39 \%$ siswa tidak pernah melakukan pembelajaran jarak jauh, dan sebagian besar (74\%) siswa setuju layanan BK dengan blended learning, 11\% siswa sangat setuju layanan BK menggunakan blended learning, hanya sangat kecil (9\%) siswa yang tidak setuju.

Berdasarkan kesimpulan dari penelitian yang dilakukan oleh Pujianti, A (2018) terlihat dari perbandingan perolehan skor pretes dan posttest layanan informasi karir yang mengalami peningkatan sebanya 16, $24 \%$. Model cyber counseling berbantuan facebook terbukti efektif untuk meningkatkan layanan informasi karir siswa di SMA. Uji keefektifan model dibuktikan melalui uji beda $t$-test dengan model uji paired sample t-test. Hasilnya diperoleh perbedaan yang signifikan yang ditujukkan oleh adanya signifikansi $0,000<0,05$ artinya ada perubahan penigkatan antara sebelum dan sesudah diberikan layanan cyber counseling berbantuan facebook, sehingga dapat dikatakan bahwa model cyber counseling berbantuan facebook efektif untuk meningkatkan layanan informasi karir siswa di SMA.

Masuknya Teknologi Informasi (TI) ke dunia pendidikan sangat membawa pengaruh besar terhadap peningkatan kualitas sumber daya manusia (SDM). Bentuk atau metoda pembelajaran yang tidak selalu dilaksanakan di dalam kelas dan juga tidak membuat siswa jenuh karena kebutuhan-kebutuhan informasi secara cepat dan mudah itu sangat dibutuhkan. Disamping itu pola pikir, wawasan pengetahuan dan skill peserta didik lebih dapat berkembang. Di era digital ini konselor harus senantiasa menciptakan berbagai inovasi kepada konseli seperti layanan akses pada teknologi yang memadai yang di terapkan pada layanan bimbingan dan konseling agar peserta didik bisa mengakses dengan mudah suatu pelajaran di era globalisasi pada saat ini dengan berbagai kemudahan dalam tugas-tugas yang ingin dibuat.

Diharapkan penelitian ini memberikan manfaat secara praktis penelitian ini diharapkan dapat memberikan manfaat konkrit berupa: Bagi siswa dapat menambah pengetahuan dan informasi guna memecahkan permasalahan yang dihadapinya melalui layanan bimbingan klasikal dengan memanfaatkan aplikasi Google Meet. Bagi guru dapat berguna menjadi sumber informasi 


\section{JURNAL ILMIAH}

BINA EDUKASI

ISSN 1979-8598 E-ISSN: 2655-8378

http://journal.binadarma.ac.id/index.php/jurnalbinaedukasi

Vol. 14, No. 2, Desember 2021, 107 - 120

dalam menerapkan dan mengembangkan pemanfaatan aplikasi Google Meet dalam pelaksanaan layanan layanan bimbingan klasikal, dan bagi sekolah/lembaga pendidikan dapat berguna untuk lebih meningkatkan kreatifitas memanfaatkan media pembelajaran dalam hal ini sebagai media dalam pelaksanaan bimbingan konseling layanan klasikal.

\section{METODOLOGI PENELITIAN}

\section{1 Bimbingan Konseling}

Prayitno dkk (2019) menjelaskan bahwa bimbingan adalah proses pemberian bantuan yang dilakukan oleh orang yang ahli kepada seorang atau beberapa orang individu baik anak-anak, remaja, maupun dewasa agar orang yang dibimbing dapat mengembangkan kemampuan dirinya sendiri dan mandiri dengan memanfaatkan kekuatan individu dan sarana yang ada dan dapat dikembangkan berdasarkan norma-norma yang berlaku.

Menurut Aqib, Z (2011) bimbingan dan konseling adalah pelayanan bantuan untuk peserta didik, baik secara perorangan maupun kelompok agar mampu mandiri dan berkembang secara optimal dalam bidang bidang pengembangan kehidupan pribadi, kehidupan social, kemampuan belajar dan perencanaan karir, melalui berbagai jenis layanan dan kegiatan pendukung berdasarkan norma-norma yang berlaku.

\subsection{Bidang Layanan Bimbingan Konseling}

1) Bimbingan konseling bidang pribadi

Proses pemberian bantuan dari guru bimbingan dan konseling kepada peserta didik untuk memahami, menerima, mengarahkan, mengambil keputusan dan merealisasikan keputusannya secara bertanggung jawab tentang perkembangan aspek pribadinya, sehingga dapat mencapai perkembangan pribadi yang optimal dan mencapai kemandirian, kebahagiaan, kesejahteraan dan keselamatan dalam kehidupannya. Aspek perkembangan peserta didik yang dikembangkan meliputi (1) memahami potensi diri dan memahami kelebihan dan kelemahannya baik kondisi fisik maupun psikis, (2) mengembangkan potensi untuk mencapai kesuksesan dalam kehidupannya, (3) menerima kelemahan kondisi diri dan mengatasinya secara baik, (4) mencapai keselarasan perkembangan antara cipta-rasa-karsa, (5) mencapai kematangan/kedewasaan ciptarasa-karsa secara tepat dalam kehidupannya sesuai nilai-nilai luhur, dan (6) mengaktualisasikan dirinya sesuai dengan potensi diri secara optimal berdasarkan nilai-nilai luhur budaya dan agama. 


\section{JURNAL ILMIAH \\ BINA EDUKASI \\ ISSN 1979-8598 E-ISSN: 2655-8378 \\ http://journal.binadarma.ac.id/index.php/jurnalbinaedukasi \\ Vol. 14, No. 2, Desember 2021, 107 - 120}

\section{2) Bimbingan konseling bidang sosial}

Proses pemberian bantuan dari guru bimbingan dan konseling kepada peserta didik untuk memahami lingkungannya dan dapat melakukan interaksi social secara positif, terampil berainteraksi social, mampu mengatasi masalah-masalah social yang dialaminya, mampu menyesuaikan diri dan memiliki keserasian hubungan dengan lingkungan sosialnyasehingga mencapai kebahagiaan dan kebermaknaan dalam dalam kehidupannya. Aspek perkembangan peserta didik yang dikembangkan meliputi (1) berempati terhadap kondisi orang lain, (2) memahami keragaman latar social, budaya, (3) menghormati dan menghargai orang lain, (4) menyesuaikan dengan nilai dan norma yang berlaku, (5) berinteraksi social yang efektif, (6) bekerjasama dengan orang lain secara bertanggung jawab, (8) mengatasi konflik dengan orang lain berdasarkan prinsip yang saling menguntungkan.

\section{3) Bimbingan konseling bidang belajar}

Proses pemberian bantuan guru bimbingan dan konseling kepada peserta didik antara lain adalah mengenali potensi diri untuk belajar, memiliki sikap dan keterampilan belajar, terampil merencanakan pendidikan, memiliki kesiapan menghadapi ujian, memiliki kebiasaan belajar teratur dan mencapai hasil belajar secara optimal sehingga dapat mencapai kesuksesan, kesejahteraan dan kebahagiaan dalam kehidupannya. Aspek perkembangan yang dikembangkan meliputi : (1) menyadari potensi diri dalam aspek belajar dan memahami berbagai hambatan belajar, (2) memiliki sikap dan kebiasaan belajar yang positif, (3) memiliki motif yang tinggi untuk belajar sepanjang hayat, (4) memiliki keterampilan belajar yang efektif, (5) memiliki keterampilan perencanaan dan penetapan pendidikan lanjutan, dan (6) memiliki kesiapan menghadapi ujian.

\section{4) Bimbingan konseling bidang karir}

Proses pemberian bantuan guru bimbingan dan konseling kepada peserta didik untuk memahami pertumbuhan, perkembangan, eksplorasi, aspirasi dan pengambilan keputusan karir sepanjang rentang hidupnya secara rasional dan realistis berdasar informasi potensi diri dan melihat kesempatan yang tersedia dilingkungan hidupnya untuk mencapai kesuksesan dalam kehidupannya. Aspek perkembangan yang dikembangkan meliputi: (1) memiliki pemahaman diri 9 kemampuan minat dan kepribadian ) yang terkait dengan pekerjaan, (2) memiliki pengetahuan mengenai dunia kerja dan informasi karir yang menunjang kematangan kompetensi karir, (3) memiliki sikap positif terhadap dunia kerja, (4) memahami relevansi kemampuan menguasai pelajaran dengan persyaratan keahlian atau keterampilan bidang pekerjaan yang menjadi cita-cita karir dimasa depan, (5) memiliki kemampuan untuk membentuk identitas karir dengan cara mengenali cirri-ciri pekerjaan, persyaratan kemampuan yang dituntut, lingkungan 


\section{JURNAL ILMIAH}

BINA EDUKASI

ISSN 1979-8598 E-ISSN: 2655-8378

http://journal.binadarma.ac.id/index.php/jurnalbinaedukasi

Vol. 14, No. 2, Desember 2021, 107 - 120

sosiopsikologis pekerjaan, prospek kerja, kesejahteraan kerja, memiliki kemampuan merencanakan masa depan, berupa kemampuan merancang kehidupan secara rasional untuk memperoleh peran-peran yang sesuai dengan minat, kemampuan dan kondisi kehidupan social ekonomi, membentuk pola-pola karir, mengenal keterampilan, serta memiliki kemampuan atau kematangan untuk mengambil keputusan karir.

\subsection{Konseling online sebagai salah satu bentuk pelaksanaan $E$-Counseling}

Zadrian, A (2013) menyatakan dunia online dapat dijadikan sarana dalam membantu guru Bimbingan dan konseling/konselor untuk meng-update pengetahuannya guna membantu menjalankan tugas, seperti mencari referensi, diskusi dan sebagainya. Seiring dengan itu penyelenggataan konseling tidak hanya dilakukan face to face $(\mathrm{FtF})$ dalam satu ruangan tertutup, namun bisa dilakukan melalui format jarak jauh dengan bantuan teknologi yang selanjutnya dikenal dengan istilah e-konseling, Gibson (2008). Istilah e-konseling berasal dari bahasa Inggris yaitu (elektronik counseling) yang berarti konseling elektronik yang secara singkat dapat diartikan yaitu proses penyelenggaraan konseling secara elektronik. Pelayanan e-konseling tidak terbatas pada penyelenggaraan konseling (istilah yang paling popular untuk menyebut konseling individu) saja, namun diperluas menjadi penyelenggaraan BK secara keseluruhan dengan bantuan teknologi. Tidak hanya online konseling melalui internet, namun juga semua aspek pemanfaatan teknologi informasi dan komunikasi lainnya dalam penyelenggaraan BK. Seperti penggunaan dan pemanfaatan pengolahan program instrumentasi, himpunan data siswa, aplikasi manajemen konseling, pemanfataan media saat pemberian layanan klasikal dikelas dan lain sebagainya termasuk juga pemanfaatan telepon untuk penyelenggaraan konseling individu.

\subsection{Media bimbingan konseling online}

Dilaksanakan secara online maupun tatap muka, keberadaan media memiliki peranan penting dalam pelaksanaan layanan bimbingan dan konseling. Media merupakan salah satu faktor penting penentu keberhasilan tercapainya tujuan dari layanan bimbingan dan konseling. Penggunaan media dalam pelaksanaan layanan bimbingan dan konseling akan membuat kegiatan layanan lebih menarik dan menyenangkan serta membantu memperjelas pesan yang ingin disampaikan atau dibahas. Sebagai salah satu komponen dalam system bimbingan konseling, maka media turut menentukan keberhasilan pelayanan bimbingan konseling. Bimbingan dan konseling sebagai proses komunikasi antara guru pembimbing (konselor) dengan siswa (konseli), maka media menjadi perantara dalam komunikasi tersebut. Tujuan utama media adalah mengefektifkan proses komunikasi pembelajaran sehingga tercapai tujuan yang diinginkan atau adanya perubahan perilaku pembelajar atau peserta didik. 


\section{JURNAL ILMIAH \\ BINA EDUKASI \\ ISSN 1979-8598 E-ISSN: 2655-8378 \\ http://journal.binadarma.ac.id/index.php/jurnalbinaedukasi \\ Vol. 14, No. 2, Desember 2021, 107 - 120}

Adapun media yang dapat digunakan dalam pelaksanaan layanan bimbingan konseling online diantaranya sebagai berikut.

1) Website

Perusahaan dan/atau para pakar bidang web developer. Konselor dapat memilih desain web yang diinginkan, mulai dari html, php, dan website yang menggunakan CMS (Content manajemen system). Penyediaan ini membutuhkan biaya yang cukup besar.

\section{2) Telephone/handphone}

Telepon/handphone dapat digunakan untuk menghubungi konselor. Konselor dapat mendengar dengan jelas apa yang diungkapkan kliennya melalui fasilitas telephone/handphone. Dengan fasilitas ini pula konselor dapat segera merespon apa yang sedang dibicarakan oleh kliennya.

3) Email

Email merupakan singkatan dari elektronik mail. Yang berarti surat elektronik. Email merupakan system yang memungkinkan pesan berbasis teks untuk dikirim dan diterima secara elektronik melalui beberapa computer atau telepon seluler.

4) Chat, instan messanging dan jejaring social

Berbagai aplikasi dapat digunakan untuk chatting ini, seperti skype, messanger, google talk, window live messanger, mIRC dan juga melalui jejaring social seperti facebook, twitter, myspace yang didalamnya juga tersedia fasilitas chating, whatsapp, telegram, instagram, line, dan lain sebagainya yang didalamnya juga tersedia fasilitas chatting.

5) Video conferencing

Video conference atau dalam bahasa Indonesia disebut video konferensi atau pertemuan melalui video dapat digunakan konselor untuk mendukung layanan bimbingan dan konseling. Manfaat media dalam pelaksanaan layanan bimbinagn dan konseling online adalah sebagai berikut.

1) memperjelas pesan agar tidak teralu verbalistis;

2) mengatasi keterbatasan ruang, waktu, tenaga dan daya indra;

3) menimbulkan gairah, minat siswa, interaksi lebih antara siswa dengan guru bimbingan dan konseling;

4) memberi rangsangan yang sama, mempersamaka pengalaman dan menimbilkan persepsi yang sama;

5) proses layanan bimbingan konseling dapat lebih menarik;

6) proses layanan bimbingan konseling menjadi lebih interaktif;

7) kualitas layanan bimbingan dan konseling dapat ditingkatkan; dan

8) sikap positif siswa terhadap materi layanan bimbinagan konseling 


\section{JURNAL ILMIAH}

BINA EDUKASI

ISSN 1979-8598 E-ISSN: 2655-8378

http://journal.binadarma.ac.id/index.php/jurnalbinaedukasi

Vol. 14, No. 2, Desember 2021, 107 - 120

\subsection{Google Meet}

Pembelajaran berbasis teknologi informasi dan komunikasi (TIK) dalam dunia pendidikan keberadaannya tidak dapat dipisahkan dengan tuntutan pembelajaran abad-21. Dalam perspektif pendidikan global, TIK merupakan soko guru (penopang) efektifnya penyelenggaraan pendidikan. Bahkan TIK dalam perkembangannya mendorong semua elemen-elemen pendidikan modern, guru, siswa, orang tua, dan sekolah dituntut untuk adaftif dalam menyikapinya Sutrisno (2012).

Berdasarkan pernyataan tersebut tidak menutup kemungkinan bagi guru bimbingan dan konseling untuk ikut ambil bagian dalam pemanfaatkan kemajuan teknologi guna kelancaran proses pelaksanaan layanan bimbingan konseling agar tercapainya tujuan dari program bimbingan konseling yang sudah dirancang oleh guru bimbingan dan konseling yaitu kemandirian peserta didik. Berbagai macam teknologi dapat dimanfaatkan oleh guru bimbingan konseling guna kelancaran proses pelayanan. Tinggal keterampilan guru bimbingan dan konseling dalam memilih dan menggunakan teknologi yang sesuai dengan layanan yang diberikan kepada siswa/klien. Salah satu teknologi yang dapat digunakan untuk pelaksanaan layanan bimbingan konseling adalah aplikasi google meet.

\subsection{Hipotesis Penelitian}

Sugiyono (2016), hipotesis merupakan jawaban sementara terhadap rumusan masalah penelitian, dimana rumusan masalah penelitian telah dinyatakan dalam bentuk kalimat pertanyaan. Dikatakan sementara, karena jawaban yang diberikan baru didasarkan pada teori yang relevan, belum didasarkan pada fakta-fakta empiris yang diperoleh melalui pengumpulan data. Hipotesis dari permasalahan di atas adalah sebagai berikut: Bagaimanakah pemanfaatan aplikasi Google Meet dalam pelaksanaan layanan bimbingan klasikal pada siswa kelas XII SMA Negeri 12 Kota Jambi.

\subsection{Metode Penelitian}

Pendekatan kualitatif diharapkan mampu menghasilkan uraian yang mendalam tentang ucapan, tulisan, dan atau perilaku yang dapat diamati dari suatu individu, kelompok, masyarakat dan atau organisasi tertentu dalam suatu keadaan konteks tertentu yang dikaji dari sudut pandang yang utuh, komprehensif dan holistik.

Metode penelitian ini adalah metode penelitian kualitif atau naturalistic karna dilakukan pada kondisi yang alamiah. Menurut (Sujarweni: 2020) mengemukakan bahwa penelitian 


\section{JURNAL ILMIAH \\ BINA EDUKASI \\ ISSN 1979-8598 E-ISSN: 2655-8378 \\ http://journal.binadarma.ac.id/index.php/jurnalbinaedukasi \\ Vol. 14, No. 2, Desember 2021, 107 - 120}

kualitatif adalah salah satu prosedur penelitian yang menghasilkan data deskriptif berupa ucapan atau tulisan dan perilaku orang-orang yang diamati. (Sugiyono: 2016) mengemukakan penelitian kualitatif merupakan payungnya semua jenis metode pendekatan penelitian yang digunakan untuk meneliti kehidupan social yang natural/alamiah.

Dalam penelitian ini, informasi yang diperoleh dianalisis secara kualitatif (nonkuantitatif). Informasi dapat berupa transkrip hasil wawancara, catatan lapangan, dokumen atau bahan-bahan yang bersifat visual seperti foto, video, bahan dari internet dan dokumen-dokumen lain tentang kehidupan manusia secara individual atau kelompok.

Penggunaan metode kualitatif ini dilakukan atas pertimbangan-pertimbangan untuk mengungkapkan pemanfaatan aplikasi google meet dalam pelaksanaan layanan bimbingan konseling layanan klasiskal di SMAN 12 Kota Jambi sehingga didapat data yang akurat dan diperlukan dalam pengamatan yang mendalam.

Teknik sampling yang sering digunakan dalam penelitian kualitatif adalah purposive sampling dan snowball sampling. Dalam penelitian ini menggunakan teknik purposive sampling yang artinya teknik pengambilan sampel sumber data dengan pertimbangan tertentu. Pertimbangan peneliti dalam menentukan subjek penelitian ini adalah mereka adalah tiga orang siswa kelas XII yang membutuhkan informasi yang terdapat dalam layanan bimbingan klasikal dan subjek penelitian yang peneliti pilih diharapkan dapat memberikan data penelitian yang peneliti butuhkan.

\subsection{Teknik Pengumpulan Data}

Dalam penelitian ini peneliti menggunakan teknik wawancara tak berstruktur yang artinya peneliti mengajukan pertanyaan-pertanyaan secara lebih bebas dan lebih leluasa, tanpa terikat oleh suatu susunan pertanyaan yang telah dipersiapkan sebelumnya, meski begitu peneliti juga menggunakan panduan wawancara yang berisi butir-butir pertanyaan yang diajukan kepada informan yaitu guru bimbingan konseling dan siswa. Panduan tersebut digunakan untuk mempermudah dalam melakukan wawancara, pengolahan data dan informasi.

\subsection{Teknik Analisis Data}

Setelah data yang dibutuhkan terkumpul perlu dilakukan analisis data atau diolah. Sugiyono (2016) mengemukakan bahwa analisis data adalah proses mencari dan menyususn secara sistematis data yang diperoleh dari hasil wawancara, catatan lapangan dan dokumentasi, dengan cara mengorganisasikan data ke dalam kategori, menjabarkan data kedalam unit-unit, 
melakukan sintesa, menyusun kedalam pola, memilih mana yang penting dan yang akan dipelajari, dan membuat kesimpulan sehingga mudah difahami oleh diri sendiri maupun orng lain.

Analisis data yang digunakan dalam penelitian ini adalah deskriptif kualitatif artinya data yang diperoleh dari penelitian tentang pemanfaatan aplikasi Google Meet dalam pelaksanaan bimbingan konseling layanan klasikal pada siswa kelas XII SMA Negeri 12 kota Jambi melalui lembar catatan wawancara dan dilaporkan apa adanya keudian dianalisis secara deskriptif untuk mendapatkan gambaran mengenai fakta yang ada. Proses analisis dalam penelitian ini bertujuan untuk menjawab data dalam penelitian.

Aktivitas dalam analisis data dimulai dengan pengumpulan data, dan penarikan kesimpulan/verifikasi. Proses analisis data dilakukan secara terus menerus didalam proses pengumpulan data selama penelitian berlangsung. Alur analisis ini digambarkan sebagai berikut

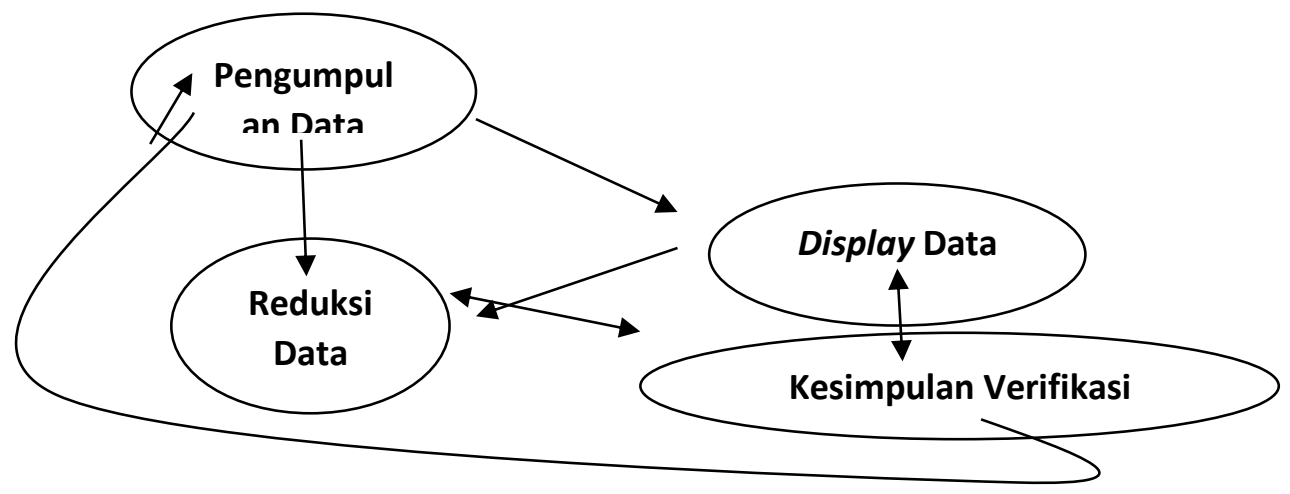

Gambar 1. Komponen analisis data model Miles and Huberman

Berdasarkan gambar di atas, maka langkah-langkah analisis data dalam penelitian ini dilakukan selama dan setelah pengumpulan data, pada proses reduksi data, penyajian data, dan penarikan kesimpulan sementara dilakukan selama pengumpulan data masih berlangsung, sedangkan untuk verifikasi dan penarikan kesimpulan akhir dilakukan setelah pengumpulan data selesai.

\section{1) Pengumpulan data}

Data yang diperoleh dari hasil wawancara dicatat dalam catatan lapangan yang terdiri dari dua bagian yaitu deskriptif dan reflektif. Catatan deskriptif adalah catatan alami atau catatan apa yang dilihat, didengar, disaksikan dan dialami sendiri oleh peneliti tanpa adanya pendapat atau penafsiran dari peneliti terhadap fenomena yang dialami. Catatan refleksi adalah catatan yang berisi kesan, komentar, pendapat dan tafsiran peneliti tentang temuan yang dijumpai dan merupakan bahan rencana pengumpulan data untuk tahap berikutnya. 


\section{JURNAL ILMIAH}

BINA EDUKASI

ISSN 1979-8598 E-ISSN: 2655-8378

http://journal.binadarma.ac.id/index.php/jurnalbinaedukasi

Vol. 14, No. 2, Desember 2021, 107 - 120

\section{2) Reduksi data}

Reduksi data adalah kegiatan menyajikan data inti atau data pokok/inti, sehingga dapat membrikan gambaran yang lebih jelas dan tajam mengenai hasil pengamatan, wawancara serta dokumentasi. Reduksi data dalam penelitian ini dengan cara menyajikan data pokok/inti yang mencakup keseluruhan hasil penelitian tanpa mengabaikan data-data pendukung, yaitu mencakup proses pemilihan, pemuatan, penyederhanaan dan informasi data kasar yang diperoleh dari catatan lapangan.

Data yang terkumpul demikian banyak dan kompleks, serta masih tercampur aduk kemudian masih direduksi. Reduksi data merupakan aktivitas memilih data. Data yang relevan dan penting yang berkaitan dengan pemanfaatan apliaksi Google Meet dalam pelaksanaan bimbingan konseling layanan klasikal. Data yang tidak terkait dengan permasalahan tidak disajikan dalam bentuk laporan.

\section{3) Display Data}

Supaya data yang banyak dan telah direduksi mudah dipahami baik oleh peneliti maupun orang lain, maka data tersebut perlu disajikan. Bentuk penyajian adalah teks naratif (pengungkapan secara tertulis). Tujuannya adalah untuk memudahkan dalam mendeskripsikan suatu peristiwa, sehingga dengan demikian memudahkan untuk mengambil suatu kesimpulan.

Analisis data pada penelitian ini menggunakan analisis data kualitatif, artinya analisis berdasarkan data observasi lapangan dan pandangan secara teoritik untuk mendeskripsikan secara jelas tentang bagaimana pemanfaatan aplikasi Google Meet dalam pelaksanaan bimbingan konseling layanan klasikal pada siswa kelas XII SMAN 12 Kota Jambi.

\section{4) Menarik kesimpulan/verifikasi}

Data yang sudah dipolakan, kemudian difokuskan dan disusun secara sistematik dalam bentuk naratif. Data tersebut disimpulkan sehingga makna data dapat ditemukan dalam bentuk tafsiran dan argumentasi. Kesimpulan juga diverifikasi selama penelitian berlangsung. Kesimpulan yang diambil sekiranya masih terdapat kekurangan, maka akan ditambahkan. 


\section{JURNAL ILMIAH}

BINA EDUKASI

ISSN 1979-8598 E-ISSN: 2655-8378

http://journal.binadarma.ac.id/index.php/jurnalbinaedukasi

Vol. 14, No. 2, Desember 2021, 107 - 120

\section{HASIL DAN PEMBAHASAN}

\subsection{Hasil Penelitian}

Penelitian ini dilakukan untuk mengamati gambaran pemanfaatan aplikasi google meet sebagai media pelaksanaan layanan bimbingan klasikal ditinjau dari 5 prinsip media pembelajaran yaitu efektivitas, relevansi, efisiensi, dapat digunakan dan kontekstual yang mana dalam hal ini media pembelajran aplikasi google meet tersebut dimanfaatkan untuk kegiatan layanan bimbingan klasikal. Berikut paparan data hasil wawancara yang peneliti lakukan di SMAN 12 Kota Jambi dengan sumber data yang dilakukan pada tanggal 23 April 2021: (1) Prinsip efektivitas pemanfaatan aplikasi google meet sebagai media pelaksanaan layanan bimbingan klasikal, (2) Prinsip relevansi pemanfaatan aplikasi google meet sebagai media pelaksanaan layanan bimbingan klasikal, (3) Prinsip efisiensi pemanfaatan aplikasi google meet sebagai media pelaksanaan layanan bimbingan klasikal, (4) Prinsip dapat digunakan pemanfaatan aplikasi google meet sebagai media pelaksanaan layanan bimbingan klasikal, (5) Prinsip kontekstual pemanfaatan aplikasi google meet sebagai media pelaksanaan layanan bimbingan klasikal.

\subsection{Interpretasi}

Hasil penelitian yang dilakukan oleh peneliti melalui wawancara dengan 5 informan mengenai pemanfaatan aplikasi google meet sebagai media pelaksanaan layanan bimbingan klasikal bagi siswa kelas XII SMAN 12 Kota Jambi menunjukkan bahwa aplikasi google meet merupakan pilihan yang tepat untuk dimanfaatkan sebagai media pelaksanaan layanan bimbingan klasikal karena memenuhi lima prinsip media pembelajaran. Prinsip tersebut antara lain efektivitas, relevansi, efisiensi, dapat digunakan dan kontekstual. Dengan berbagai fitur canggih yang dimiliki aplikasi google meet dan kemudahan dalam penggunaannya memungkinkan untuk penyajian materi dalam format klasikal, penyajian materipun dapat diaplikasikan guru secara kreatif sehingga menarik minat peserta didik untuk mengikuti kegiatan layanan, kegiatan layanan bimbingan klasikal dengan memanfaatkan aplikasi google meet pun dapat dilakukan kapan saja dan dimana saja.

\section{SIMPULAN}

Berdasarkan hasil penelitian dan pembahasan dapat disimpulkan pemanfaattan aplikasi google meet sebagai media pelaksanaan layanan bimbingan klasikal pada siswa kelas XII SMAN 12 Kota Jambi memenuhi lima prinsip media pembelajaran. Adapun prinsip media pembelajaran tersebut antara lain efektivitas, relevansi, efisiensi, dapat digunakan dan kontekstual. Meskipun ada beberapa kelemahan dari aplikasi google meet yaitu dalam penggunaannya sangat bergantung 


\section{JURNAL ILMIAH}

BINA EDUKASI

ISSN 1979-8598 E-ISSN: 2655-8378

http://journal.binadarma.ac.id/index.php/jurnalbinaedukasi

Vol. 14, No. 2, Desember 2021, 107 - 120

dengan keadaan signal dan penggunaan kuota yang cukup besar. Aplikasi google meet dapat dijadikan solusi pemecahan masalah layanan bimbingan klasikal yang tidak terjadwal di kelas, karena dengan memanfaatkan aplikasi google meet layanan bimbingan klasikal dapat dilakukan di mana saja dan kapan saja tanpa mengganggu jam pelajaran.

Peneliti selanjutnya diharapkan dapat memanfaatkan penelitian ini sebagai bahan acuan dalam melaksanakan penelitian berikutnya dan memperbaiki kekurangan dalam penelitian ini serta dapat mengembangakan aplikasi google meet sebagai media pelaksanaan layanan bimbingan konseling bagi siswa sekolah menengah atas.

\section{DAFTAR PUSTAKA}

Atmoko A, Indreswari H, Simon IM, Utami NW, Bariyyah K, (2018). Analisis Kebutuhan Siswa Dalam Layanan konseling Berbasis Blanded Learning Dan Implikasinya Terhadap Pengembangan Karakter. Universitas Negeri Malang. Malang.

Aqib Z, (2011). Bimbingan Konseling Di sekolah. YRAMA WIDYA: Surabaya.

Bangun, N., \& Saragih, A. H. (2015). Pengembangan Media Web Bimbingan Konseling. Jurnal Teknologi Informasi \& Komunikasi dalam Pendidikan, 2(1).

Gibson.A, Andi \& Kurniawan (2008). Multimedia learning. In Journal Psychology of learning and motivation (Vol. 41, pp. 85-139). Academic Press.

Kurniawa. T \& Winingsih. E. (2019). Pengembangan Aplikasi Pengenalan Bimbingan Dan Konseling Berbasis Android Sebagai Media Layanan Informasi Untuk Siswa Smp Negeri 3 Gresik. Jurnal BK UNESA, 7(2).

Miles and Huberman (2019). Penelitian Kualitatif. Pustaka Barupres: Yogyakarta.

Prayitno. (2019). Konseling Profesional Yang Berhasil. Raja Grafindo Persada: Depok.

Pujiyanti, A. (2018). Pengembangan Model Cyber Counseling Berbantuan Facebook Untuk Meningkatkan Efektivitas Layanan Informasi Karier Di Sma Negeri 1 Semarang. Prosiding, Vol.22.

Sugiyono (2016). Metode Penelitian Pendidikan (Kuantitatif, Kualitatif, Kombinasi, R\&D dan Penelitian Pendidikan). Alfabeta: Bandung.

Sujarweni, VW. (2020). Metodologi Penelitian. Pustaka Barupres: Yogyakarta.

Sutrisno (2012). Kreatif Mengembangkan Aktivitas Pembelajaran Berbasis TIK. Referensi: Jakarta.

Zadrian, A. (2013). Media pembelajaran.PT Raja Grafindo Persada: Jakarta. 